\title{
ARTICLE
}

Interventions and public health nutrition

\section{Dietary micronutrient intakes among women of reproductive age in Mumbai slums}

\author{
Rebecca L. Nunn ${ }^{1}$ - Sarah H. Kehoe ${ }^{1}$ Harsha Chopra ${ }^{2}$ - Sirazul A. Sahariah ${ }^{2}$ - Meera Gandhi ${ }^{2}$ Chiara Di Gravio ${ }^{1}$. \\ Patsy J. Coakley ${ }^{1} \cdot$ Vanessa A. Cox $^{1} \cdot$ Harshad Sane ${ }^{2} \cdot$ Devi Shivshankaran $^{2} \cdot$ Ella Marley-Zagar $^{1}$. \\ Barrie M. Margetts ${ }^{3} \cdot$ Alan A. Jackson $^{4} \cdot$ Ramesh D. Potdar $^{2} \cdot$ Caroline H. D. Fall $^{1}$
}

Received: 4 September 2018 / Revised: 21 January 2019 / Accepted: 22 March 2019 / Published online: 31 May 2019

(c) The Author(s) 2019. This article is published with open access

\begin{abstract}
Objectives To (1) describe micronutrient intakes among women of reproductive age living in Mumbai slums; (2) assess the adequacy of these intakes compared with reference values; (3) identify important dietary sources of micronutrients.

Subjects/methods Participants were 6426 non-pregnant women aged 16-39 years, registered in a randomised controlled trial of a food-based intervention set in the Bandra, Khar and Andheri areas of Mumbai, India. Cross-sectional quantified food frequency questionnaire (FFQ) data were collected. Vitamin $(n=9)$ and mineral $(n=6)$ intakes were calculated and analysed in relation to dietary reference values (DRVs). Important dietary sources were identified for each micronutrient. Results Median intakes of all micronutrients, except vitamin E, were below the FAO/WHO reference nutrient intake (RNI). Intakes of calcium, iron, vitamin A and folate were furthest from the RNI. For seven of the micronutrients, over half of the women had intakes below the lower reference nutrient intake (LRNI); this figure was over $75 \%$ for calcium and riboflavin. The majority of women $(93 \%)$ had intakes below the EAR for 5 or more micronutrients, and $64 \%$ for 10 or more. Adolescents had lower intakes than women aged $>19$ years. Less than $1 \%$ of adult women and no adolescents met the EAR for all micronutrients. Animal source foods and micronutrient-rich fruit and vegetables were consumed infrequently.

Conclusions These women had low intakes of multiple micronutrients, increasing their risk of insufficiency. There is a need to determine the factors causing poor intakes, to direct interventions that improve diet quality and nutritional sufficiency.
\end{abstract}

\section{Introduction}

Micronutrient deficiencies are a serious public health problem among women of reproductive age in low- and middle-income countries (LMICs) [1-4]. WHO states that malnutrition is directly or indirectly linked to major causes of death and disability worldwide [5-7]. Over 2 billion people (most of whom live in LMICs) are estimated to be

Sarah H. Kehoe

sk@mrc.soton.ac.uk

1 MRC Lifecourse Epidemiology Unit, University of Southampton, Southampton, UK

2 Centre for the Study of Social Change, Mumbai, India

3 Public Health Nutrition, Faculty of Medicine, University of Southampton, Southampton, UK

4 National Institute for Health Research, Southampton Biomedical Research Centre, Southampton, UK deficient in one or more vitamins and minerals, particularly iron, zinc and vitamin A [2, 4, 8, 9]. In India, iron, vitamin A and vitamin B12 deficiencies are widespread in lowincome populations, children and pregnant women [10-12]. Micronutrient requirements increase during pregnancy. This can exacerbate existing insufficiencies resulting in adverse maternal outcomes [9, 13]. Poor-quality diets before pregnancy may contribute to birth defects, intrauterine growth restriction [1, 14] and infant stunting [15].

The main direct cause of micronutrient deficiencies is insufficient intakes [16]. Low bioavailability is also a factor for some micronutrients. Intakes are low when access to micronutrient-rich foods and fortified foods is limited $[1,17]$, usually because they are expensive [18], locally unavailable or unacceptable for cultural or religious reasons [19]. Diets in India are often poor quality, carbohydrate rich [20-22] and lacking in micronutrient-rich foods [11]. 'Animal source' foods are rich in protein, iron and vitamin B12, yet in the state of Maharashtra, fewer than $2 \%$ of women reported daily consumption of meat/chicken or fish and $35 \%$ 
never ate them [12]. Vegetarian diets diverse enough to provide adequate micronutrients may not be affordable. Fruit and vegetable intakes in India are often below the recommended five portions per day [22-25].

There is a lack of data on micronutrient intakes of women of reproductive age, and important dietary sources, in India. Most research has focused on rural populations [11, 26, 27], with few studies in urban settings [10]. Investigations have mainly focused on pregnant women; few have studied preconceptional women of reproductive age or compared intakes of adults and adolescents against the respective recommended intakes. Studies typically focus on iodine, iron, vitamin A, vitamin B12, folate, and vitamin $\mathrm{C}$ [10], but few have investigated a wide range of micronutrients linked to dietary sources [26, 28].

The aim of this study is to provide a unique insight into food and micronutrient consumption of a large cohort of women of reproductive age living in Mumbai slums. Our objectives were to (1) describe micronutrient intakes amongst these women; (2) assess the adequacy of these intakes against references; (3) identify important dietary sources of micronutrients.

\section{Methods}

Data were collected during registration for the Mumbai Maternal Nutrition Project (MMNP), a randomised controlled efficacy trial in India to investigate the effects of daily consumption of a food-based micronutrient-rich supplement on infant outcomes [29].

\section{Setting and participants}

The trial took place from January 2006 to May 2012 in the Bandra, Khar, Santa Cruz and Andheri areas of the city of Mumbai, India. The setting was the slum areas covered by the health and social programmes of the non-governmental organisation the Centre for the Study of Social Change (CSSC). Women were eligible if aged $<40$ years, married, non-pregnant, not sterilised, planning to have more children and intending to deliver in Mumbai. Women were recruited at a range of locations close to their homes. Community meetings were held to obtain community consent and answer questions (full recruitment methods in Potdar et al. [29]).

\section{Demographic and anthropometric data}

Data on age, education, religion, first language, occupation and socio-economic status were collected by interview. Educational attainment was recorded in seven groups ranging from illiterate to post-graduate. Socio-economic status was assessed using the Standard of Living Index from the
Indian National Family Health Survey, which is based on housing type, utilities and household possessions [30]. Weight and height were measured using standardised techniques. Height was measured to the nearest $0.1 \mathrm{~cm}$ using a Harpenden portable stadiometer (CMS Instruments Ltd, London, UK) and weight to the nearest $10 \mathrm{~g}$ using digital weighing scales (SECA, Hanover, MD, USA).

\section{Dietary data}

Dietary intakes were assessed using a 212-item food frequency questionnaire (FFQ) developed specifically for MMNP. The FFQ was administered in Hindi or Marathi by a nutritionist or trained project assistant at the time of registration. Women were asked how often they had consumed each food item in the previous 7 days and the usual portion size. Data were recorded as frequency codes (D1 = once a day, D2 = twice a day, W1 = once a week etc.). Portion size was determined using standardised local measurements demonstrated visually to participants using a range of different sized spoons, bowls and chapatti (Indian unleavened bread) templates. All weights used in subsequent calculations were related to the edible proportion of the food.

\section{Nutrient intake calculations}

Intake frequencies and reported portion sizes were used to calculate weekly intake weights of each food item for each woman. Dietary intakes of energy, macronutrients and micronutrients were calculated using McCance and Widdowson's 'The Composition of Foods' integrated dataset versions 5 and 6 [31]. This programme was chosen because composition data were available for all foods for the nutrients of interest. For foods prepared at home $(n=164)$, at least two household recipes were obtained from women living in the study area, nutrient content was calculated as described below and values were averaged. For each recipe, all ingredients were weighed in the project kitchen to the nearest gram using electronic scales. The food was then cooked and the cooked dish was weighed. The nutrient content of cooked food was calculated as follows:

Nutrient content per gram of cooked food $=\frac{\text { Total nutrient content of raw ingredients }}{\text { Weight of cooked food }(\mathrm{g})}$

For each nutrient, we used the recommended conversion factors in the database to allow for nutrient losses, due to the method of cooking. For raw or unprepared items such as fruit or milk ( $n=30)$, and for shop-bought items such as biscuits or packaged drinks $(n=28)$, values were taken directly from the database of foods that were the same or as close as possible in nutritional content to the FFQ items. For foods containing beta-carotene, a ratio of $6: 1$ was used to calculate retinol equivalents. 


\section{Dietary reference values}

The dietary reference values (DRVs) used for analysis came from two sources. Reference nutrient intakes (RNIs) were taken from FAO/WHO 2011 [32], as these were the most up-to-date international reference values. The Indian Council of Medical Research recommendations were not available for all of the nutrients of interest. On inspection, the values were similar to the FAO/WHO values. Estimated average requirements (EARs) and lower reference nutrient intakes (LRNIs) from the 1990 UK COMA report [33] were used, as values were not available from FAO/WHO. LRNI values were available for all micronutrients, except for vitamin $\mathrm{E}$. Where COMA EARs were not available, vitamin E [34] and selenium [35] values from the American Institute of Medicine (IOM) Food and Nutrition Board were used. Bioavailability was assumed to be $10 \%$ for iron and 'low' for zinc, in line with bioavailability evidence $[36,37]$ and previous studies with similar populations/dietary patterns [16]. EARs were predominantly used for analysis, as they demonstrate adequacy for $50 \%$ of a population. Using the LRNI may show serious deficiency risk, but loses some detail of the data distribution and may overestimate the percentage of adequate intakes and underestimate inadequate intakes.

\section{Data analysis}

Data from women with total energy intakes outside the range of the mean $\pm 3 \mathrm{SD}$ (standard deviations) were excluded, as this suggests over- or under-reporting or an exceptional week. Descriptive data are presented as means and standard deviations for normally distributed variables, and median (IQR) for non-normally distributed variables. Ratios were calculated for the intake against the age-specific RNI of each micronutrient. As some DRVs are different for adolescents and adult women, daily micronutrient intakes, comparison of intakes with DRVs, multiple EARs not met and RNI ratios were analysed separately for adolescents $(<19$ years of age) and adult women $(\geq 19$ years of age). The chi-square test was used to investigate the differences between adults and adolescents in meeting the EAR (Fisher's exact test if any cell had a count $<5$ ). Statistical significance was set at $p=0.05$. Odds ratios, with $95 \%$ confidence intervals $(\mathrm{CI})$, were calculated for the odds of the EAR being met by adults relative to adolescents. Statistical analyses were carried out using SPSS version 21.0 and STATA version 14 .

FFQ foods were grouped into the following 10 categories for analysis: dishes made wholly or predominantly from (1) grains, roots or tubers; (2) pulses, legumes or nuts; (3) vegetables; (4) fruits; (5) fried snacks; (6) meat or meat products; (7) fish or shellfish; (8) eggs; (9) milk or other dairy products (not eggs); (10) sugar, sweets, condiments or beverages. Intakes of micronutrients were presented as the total intake from each food group, as a percentage of the total intake of that micronutrient.

\section{Results}

\section{Descriptive characteristics}

A total of 6513 women were eligible and participated in MMNP. We excluded 87 (1.4\%) women from the analysis, because of implausible energy intakes. This left 6426 women with complete dietary data. Median age was 25 years and over three-quarters had completed at least secondary-level education (Table 1). The majority were of Hindu or Muslim faith and over half spoke Marathi as their first language. Recruitment took place throughout the year, though fewer women were recruited in the pre-monsoon season. The median (range; IQR) body mass index (BMI) was $20.0(10.8-46.9 ; 17.9-22.9) \mathrm{kg} / \mathrm{m}^{2}$. Approximately half of the women were of normal BMI and a third were underweight.

\section{Food group consumption}

Dishes predominantly made of grains, roots or tubers were consumed frequently, as were dishes containing pulses, legumes or nuts (Table 2). These two food groups contributed the largest proportion of energy. Mean intake frequencies of fruits and vegetables were low in relation to Indian food-based recommendations [38]. Approximately $80 \%$ of women consumed both in the 7-day period, but $50 \%$ ate fruit no more than twice per week. Fried snacks were frequently consumed; at least $25 \%$ of women consumed them at least four times per week.

The mean consumption frequency of meat and meat products was low. The frequency of intakes of eggs, fish and shellfish dishes were low in relation to Indian foodbased dietary guidelines [38] and their contribution to energy intakes was also low. Over $50 \%$ of women did not consume fish or shellfish and at least $25 \%$ did not consume eggs. In total, $75 \%$ of women consumed milk and milk products at least 13 times in the 7-day period, of which around $50 \%$ was tea or coffee with milk. In total, $50 \%$ of women consumed sugar, sweets, condiments and beverages three or more times.

\section{Micronutrient intakes and dietary reference values}

Dietary intakes were low in relation to recommendations for most of the micronutrients studied, with the exception of vitamins B6, C and E (Table 3). Median intakes of all 
Table 1 Descriptive characteristics of women studied

\begin{tabular}{|c|c|c|}
\hline & Median & IQR \\
\hline Age (years) $(n=6426)$ & 25 & $22-28$ \\
\hline \multirow[t]{2}{*}{ BMI $\left(\mathrm{kg} / \mathrm{m}^{2}\right)(n=6420)$} & 20.0 & $17.9-22.9$ \\
\hline & Mean & SD \\
\hline \multirow[t]{2}{*}{ Standard of Living Index score $(n=6077)$} & 24.5 & 6.1 \\
\hline & $n$ & $\%$ \\
\hline \multicolumn{3}{|l|}{ Age $(n=6426)$} \\
\hline Aged $16-18$ years & 188 & 2.9 \\
\hline Aged $\geq 19$ years & 6238 & 97.1 \\
\hline \multicolumn{3}{|l|}{ Education $(n=6419)$} \\
\hline $\begin{array}{l}\text { Postgraduate, graduate and higher secondary } \\
\text { education }\end{array}$ & 1130 & 17.6 \\
\hline Secondary education & 4491 & 70.0 \\
\hline All other (including primary and illiterate) & 797 & 12.4 \\
\hline \multicolumn{3}{|l|}{ Religion $(n=6420)$} \\
\hline Hindu & 4525 & 70.5 \\
\hline Muslim & 1620 & 25.2 \\
\hline Other & 275 & 4.3 \\
\hline \multicolumn{3}{|l|}{ First language $(n=6416)$} \\
\hline Marathi & 3314 & 51.7 \\
\hline Hindi & 2408 & 37.5 \\
\hline Other & 694 & 10.8 \\
\hline \multicolumn{3}{|l|}{ Year of recruitment $(n=6425)$} \\
\hline 2006 & 1289 & 20.1 \\
\hline 2007 & 1418 & 22.1 \\
\hline 2008 & 1272 & 19.8 \\
\hline 2009 & 1148 & 17.9 \\
\hline 2010 & 1145 & 17.8 \\
\hline 2011 & 153 & 2.4 \\
\hline \multicolumn{3}{|l|}{ Season of recruitment $(n=6425)$} \\
\hline Winter (January-February) & 1467 & 22.8 \\
\hline Pre-monsoon (March-May) & 1146 & 17.8 \\
\hline Monsoon (June-September) & 2199 & 34.2 \\
\hline Post monsoon (October-December) & 1613 & 25.1 \\
\hline \multicolumn{3}{|l|}{$B M I(n=6420)$} \\
\hline Underweight $\left(\mathrm{BMI}<18.5 \mathrm{~kg} / \mathrm{m}^{2}\right)$ & 2060 & 32.1 \\
\hline Normal range (BMI $18.5-25 \mathrm{~kg} / \mathrm{m}^{2}$ ) & 3446 & 53.6 \\
\hline Overweight (BMI >25 kg/m²) & 737 & 11.5 \\
\hline Obese $\left(\right.$ BMI $\left.>30 \mathrm{~kg} / \mathrm{m}^{2}\right)$ & 177 & 2.8 \\
\hline
\end{tabular}

micronutrients, except vitamin E, were below the RNI. Intakes of calcium, iron, vitamin $\mathrm{A}$ and folate were furthest from the RNI, each with a median ratio below 0.4. For magnesium, $43.9 \%$ of all women had intakes below the LRNI, only $16.5 \%$ of adolescents met the EAR and $24.5 \%$ met the slightly lower RNI. For selenium, $66.1 \%$ of women were consuming intakes below the RNI [32], which is lower than the EAR [35] and LRNI, and 93.2\% were consuming below the EAR. There was variation in the proportion achieving different levels of DRVs for each micronutrient (Fig. 1). The profiles of calcium and riboflavin were the poorest, with over $75 \%$ not meeting the LRNI. Over half were consuming below the LRNI of calcium, iron, selenium, vitamin $\mathrm{A}$, riboflavin and niacin. Over $80 \%$ were consuming below the EAR for calcium, iron, selenium, vitamin A, riboflavin and niacin. Over $50 \%$ met the EAR for thiamine, vitamin B6 and vitamin C. Significantly fewer adolescents than adults were meeting the EAR for calcium, magnesium, zinc, thiamine, niacin, vitamin $\mathrm{B} 6$ and vitamin $\mathrm{E}$ ( $p<0.05$ for all). Odds ratios for the EAR being met (adults compared with adolescents) were as follows: calcium OR 10.4 (95\% CI: 2.6, 41.8), magnesium $3.9(2.6,5.7)$, zinc $1.5(1.1,2.0)$, thiamine 2.0 $(1.5,2.7)$, niacin $2.4(1.4,4.3)$, vitamin B6 $1.8(1.0,3.2)$ and vitamin E $1.4(1.1,1.9)$.

\section{Multiple micronutrient insufficiencies}

The majority of women had intakes below the EAR for at least 5 micronutrients, and half for 10 or more (Fig. 2). Half of the adults were not meeting the EAR for 9-14 micronutrients. Half of the adolescents were not meeting the EAR for 10-14 micronutrients. Over half (49.6\%) of the adults and $61.2 \%$ of adolescents had intakes below the EAR for 10 micronutrients or more $\left(\chi^{2}=9.72, p<0.001\right)$.

\section{Important dietary sources of micronutrients}

Grains, roots and tubers were important sources of iron, magnesium, selenium, zinc, thiamine, niacin, vitamin B6 and folate (Fig. 3). This group also contributed to vitamin B12 intakes, due to dairy foods, such as ghee, used in these dishes. Pulses, legumes and nuts contributed over $15 \%$ of the intakes of iron, selenium, folate and vitamin $\mathrm{C}$.

Despite low intake frequencies, vegetables provided important dietary contributions of vitamin $\mathrm{A}$ and vitamin $\mathrm{C}$, and smaller contributions of calcium, iron, thiamine, riboflavin, vitamin B6 and folate. Of the women consuming vegetable dishes, $90 \%$ consumed GLVs, which contributed large amounts of the total vitamin A (98\%), vitamin C (69\%) and other micronutrients (over $70 \%$ of each) from vegetable dishes. Fruits contributed around $30 \%$ of vitamin C, $6 \%$ of vitamin B6 and $5 \%$ of vitamin A.

Milk and other dairy products were an important source of calcium $(43 \%)$, vitamin A (18\%), riboflavin (46\%) and vitamin B12 (67\%). Eggs, fish and shellfish were important sources of vitamin B12, contributing $7 \%$ and $12 \%$, respectively, of the total intakes of $\mathrm{B} 12$, but contributed $<5 \%$ of all other micronutrients. Sugar, sweets, condiments and beverages provided $<10 \%$ of most micronutrients, except vitamin A (17\%). 
Table 2 The frequency of consumption of food groups and their contribution to total energy intake

\begin{tabular}{|c|c|c|c|}
\hline Food group & $\begin{array}{l}\text { Contribution to total } \\
\text { energy }(\%)\end{array}$ & $\begin{array}{l}\text { Intake frequency per } \\
\text { week Median (IQR) }\end{array}$ & $\begin{array}{l}\text { Women consuming this food } \\
\text { group in the last week }(\%)\end{array}$ \\
\hline 1. Grains, roots or tubers & 59.6 & $33(28,39)$ & 99.9 \\
\hline $\begin{array}{l}\text { 2. Pulses, legumes } \\
\text { or nuts }\end{array}$ & 11.7 & $14(8,19)$ & 99.6 \\
\hline 3. Vegetables & 1.9 & $8(3,11)$ & 95.0 \\
\hline 4. Fruits & 2.0 & $2(1,5)$ & 84.7 \\
\hline 5. Fried snacks & 3.4 & $2(1,4)$ & 77.0 \\
\hline 6. Meat or meat products & 5.8 & $1(0,2)$ & 58.3 \\
\hline 7. Fish or shellfish & 1.6 & $0(0,1)$ & 46.4 \\
\hline 8. Eggs & 1.2 & $1(0,1)$ & 51.4 \\
\hline $\begin{array}{l}\text { 9. Milk or other dairy } \\
\text { products }\end{array}$ & 7.3 & $14(13,17)$ & 95.4 \\
\hline $\begin{array}{l}\text { 10. Sugar, sweets, } \\
\text { condiments or beverages }\end{array}$ & 5.4 & $3(1,7)$ & 89.0 \\
\hline
\end{tabular}

\section{Discussion}

\section{Micronutrient intakes}

We found that women of reproductive age living in Mumbai slums had dietary intakes of many important micronutrients below recommendations, with many having low intakes of multiple micronutrients. Our findings are in line with similar studies in India [10, 11] and other LMICs [2, 8, 16, 39], suggesting that this is a common problem among women of reproductive age. Although low reported intakes are not always associated with clinical deficiency [40-42], studies have demonstrated associations between low intakes and low circulating concentrations of iron [11], zinc [11] and folate [43, 44]. At least $50 \%$ of women had intakes of calcium, iron, selenium, vitamin A, riboflavin and niacin below the LRNI, an amount that is sufficient for the $3 \%$ of the population with the lowest requirements, indicating a serious risk of deficiency. Thiamine, vitamin B6 and vitamin $\mathrm{C}$ were the only nutrients for which at least $50 \%$ of women met the EAR, suggesting that some women are not consuming enough of the other micronutrients to meet their needs. Over $50 \%$ of women had intakes below the EAR for at least 10 micronutrients concurrently, suggesting that diets are generally nutritionally inadequate. Studies have shown interactions between micronutrients [45-47], indicating that insufficiencies of certain nutrients may exacerbate deficiencies of other micronutrients [48, 49] or reduce the effectiveness of supplementation [43].

\section{Dietary reference values}

The DRVs are intended to indicate the dietary intakes necessary to maintain adequate nutritional status. Each of them was developed using the best available evidence at the time, and we recognise that the robustness of this evidence has changed with time and varies between nutrients, precluding precise conclusions regarding adequacy. For some nutrients, the LRNI, EAR and RNI are inconsistent across the different reference documents [32-35]. This is most marked for selenium; the FAO RNI [32] is substantially lower than the COMA LRNI [33] and American IOM EAR [35]. FAO used the same experimental data as COMA and IOM, but applied different calculations. FAO also assumed lower body weights, appropriate for LMICs. The choice of a boundary to define the reference points within the distribution of requirements, can modify interpretation of the adequacy of the intakes substantially, and since the evidence upon which reference lines are based is limited, there is a continuing need for data to refine them for different populations.

\section{Strengths and limitations}

We collected data from a large, rarely studied population of urban slum-dwelling women before they became pregnant, providing novel information on intakes of several micronutrients. The FFQ featured a comprehensive list of foods derived from extensive community and pilot work. However, FFQs carry recognised potential for imprecision, recall errors and over- and under-reporting. Conversely, the monotonous diets of Indian women may enhance the accuracy. There were no biomarker data with which to validate the FFQ, because there was concern that blood sampling would discourage participation. We used food composition data from a UK-based database, because there was no available up-to-date Indian database. This could introduce error due to differences in nutrient content between UK and Indian foods. For example, selenium content of foods varies significantly according to soil concentrations. Iron bioavailability may have been under-estimated, as iron status has an impact upon absorption, with higher absorption in individuals with lower iron stores [50]. 
Table 3 Micronutrients-recommendations and summary intakes for adolescents aged 15-18 years $(n=188)$ and adult women $(n=6238)$

\begin{tabular}{|c|c|c|c|c|c|c|c|}
\hline \multirow[t]{2}{*}{ Micronutrient (unit) } & \multirow[t]{2}{*}{$\begin{array}{l}\text { Age } \\
\text { (years) }\end{array}$} & \multirow[t]{2}{*}{$\begin{array}{l}\text { EAR } \\
\text { (per day) }\end{array}$} & \multirow[t]{2}{*}{$\begin{array}{l}\text { RNI } \\
\text { (per day) }\end{array}$} & \multirow[t]{2}{*}{ Intake (median, IQR) } & \multicolumn{2}{|c|}{$\begin{array}{l}\text { Percentage of women } \\
\text { with intakes }\end{array}$} & \multirow[t]{2}{*}{$\begin{array}{l}\text { Ratio of intake to RNI } \\
\text { (median, IQR) }\end{array}$} \\
\hline & & & & & $>$ EAR & $>$ RNI & \\
\hline \multirow[t]{2}{*}{ Calcium (mg) } & $15-18$ & 625 & 1300 & $280(189,386)$ & 1.1 & 0 & $0.22(0.15,0.30)$ \\
\hline & $19-50$ & 525 & 1000 & $293(221,398)$ & 1.0 & 0.2 & $0.29(0.22,0.40)$ \\
\hline \multirow[t]{2}{*}{ Iron $(\mathrm{mg})^{\mathrm{a}}$} & $15-18$ & 11.4 & 31 & $7.2(5.3,9.6)$ & 12.2 & 0 & $0.23(0.17,0.31)$ \\
\hline & $19-50$ & 11.4 & 29.4 & $7.9(6.2,10.1)$ & 15.1 & 0 & $0.27(0.21,0.34)$ \\
\hline \multirow[t]{2}{*}{ Magnesium (mg) } & $15-18$ & $250^{\mathrm{b}}$ & $220^{\mathrm{b}}$ & $171(123,220)$ & $16.5^{\mathrm{b}}$ & $24.5^{\mathrm{b}}$ & $0.78(0.56,0.99)$ \\
\hline & $19-50$ & 200 & 220 & $189(148,237)$ & 43.3 & 32.2 & $0.86(0.67,1.08)$ \\
\hline \multirow[t]{2}{*}{ Selenium $(\mu \mathrm{g})$} & $15-18$ & $45^{\mathrm{c}}$ & 26 & $22.8(16.9,28.9)$ & 3.2 & 31.4 & $0.88(0.65,1.11)$ \\
\hline & $19-50$ & $45^{\mathrm{c}}$ & 26 & $22.5(17.8,28.8)$ & 3.8 & 33.8 & $0.87(0.69,1.11)$ \\
\hline \multirow[t]{2}{*}{ Zinc (mg) } & $15-18$ & 5.5 & 14.4 & $4.80(3.69,6.14)$ & 34.6 & 0 & $0.33(0.26,0.43)$ \\
\hline & $19-50$ & 5.5 & 9.8 & $5.24(4.20,6.39)$ & 43.4 & 1.4 & $0.58(0.47,0.71)$ \\
\hline \multirow[t]{2}{*}{ Vitamin A ( $\mu \mathrm{g}$ RE) } & $15-18$ & 400 & 600 & $198(135,296)$ & 11.7 & 3.2 & $0.33(0.23,0.49)$ \\
\hline & $19-50$ & 400 & 500 & $196(131,290)$ & 11.1 & 5.2 & $0.39(0.26,0.58)$ \\
\hline \multirow[t]{2}{*}{ Thiamine (B1) (mg) } & $15-18$ & 0.63 & 1.0 & $0.69(0.49,0.88)$ & 60.6 & 18.1 & $0.69(0.49,0.88)$ \\
\hline & $19-50$ & 0.58 & 1.1 & $0.75(0.58,0.94)$ & 75.7 & 12.1 & $0.68(0.53,0.85)$ \\
\hline \multirow[t]{2}{*}{ Riboflavin (B2) (mg) } & $15-18$ & 0.9 & 1.0 & $0.48(0.33,0.64)$ & 5.9 & 2.7 & $0.47(0.33,0.64)$ \\
\hline & $19-50$ & 0.9 & 1.1 & $0.5(0.37,0.67)$ & 9.6 & 3.8 & $0.45(0.34,0.61)$ \\
\hline \multirow[t]{2}{*}{ Niacin (B3) $(\mathrm{mg} \mathrm{NE})^{\mathrm{e}}$} & $15-18$ & 11.6 & 16 & $5.42(3.73,8.55)$ & 6.9 & 1.6 & $0.34(0.23,0.54)$ \\
\hline & $19-50$ & 10.7 & 14 & $6.99(4.73,9.28)$ & 15.3 & 4.0 & $0.50(0.34,0.66)$ \\
\hline \multirow[t]{2}{*}{ Vitamin B6 (mg $)^{\mathrm{f}}$} & $15-18$ & 0.6 & 1.2 & $1.09(0.83,1.33)$ & 93.1 & 36.7 & $0.91(0.69,1.11)$ \\
\hline & $19-50$ & 0.6 & 1.3 & $1.15(0.93,1.41)$ & 96.1 & 34.2 & $0.89(0.71,1.08)$ \\
\hline \multirow[t]{2}{*}{ Vitamin B12 $(\mu \mathrm{g})$} & $15-18$ & 1.25 & 2.4 & $1.09(0.68,1.54)$ & 41.0 & 7.4 & $0.46(0.28,0.64)$ \\
\hline & $19-50$ & 1.25 & 2.4 & $1.15(0.73,1.73)$ & 44.2 & 11.2 & $0.48(0.30,0.72)$ \\
\hline \multirow[t]{2}{*}{ Folate ( $\mu \mathrm{g}$ DFE) } & $15-18$ & 150 & 400 & $119(92,155)$ & 26.6 & 0 & $0.30(0.23,0.39)$ \\
\hline & $19-50$ & 150 & 400 & $130(103,161)$ & 31.9 & 0 & $0.32(0.26,0.40)$ \\
\hline \multirow[t]{2}{*}{ Vitamin C (mg) } & $15-18$ & 25 & 40 & $36.3(24.6,57.2)$ & 73.4 & 43.6 & $0.91(0.62,1.43)$ \\
\hline & $19-50$ & 25 & 45 & $37.3(26.4,54.5)$ & 78.3 & 36.6 & $0.83(0.59,1.21)$ \\
\hline \multirow[t]{2}{*}{ Vitamin E (mg $\alpha$-TE) } & $15-18$ & $12^{\mathrm{c}}$ & 7.5 & $10.5(7.79,14.7)$ & 40.4 & 79.3 & $1.39(1.05,1.96)$ \\
\hline & $19-50$ & $12^{\mathrm{c}}$ & 7.5 & $11.9(8.98,15.7)$ & 49.3 & 86.0 & $1.59(1.20,2.09)$ \\
\hline \multirow[t]{2}{*}{ Energy (kcal) } & $15-18$ & $2110^{\mathrm{g}}$ & - & $1261(996,1590)$ & 6.4 & - & $0.60(0.47,0.75)^{\mathrm{h}}$ \\
\hline & $19-50$ & $1940^{\mathrm{g}}$ & - & $1299(1052,1601)$ & 9.7 & - & $0.67(0.54,0.83)^{\mathrm{h}}$ \\
\hline
\end{tabular}

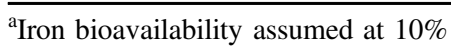

${ }^{\mathrm{b}}$ For magnesium, the values for adolescent EAR are higher than the adolescent RNI value

${ }^{c}$ EARs from Food and Nutrition Board, Institute of Medicine and National Academies [34, 35], not COMA [33]

${ }^{\mathrm{d}}$ Thiamine DRVs calculated using LRNI based upon $0.23 \mathrm{mg} / 1000 \mathrm{kcals}$, EAR based on $0.3 \mathrm{mg} / 1000 \mathrm{kcals}$. Calculated based on energy requirements taken as EARs for 15-18-year-old females (2110 kcals) and 19-50-year-old females (1940 kcals)

${ }^{\mathrm{e}}$ Niacin DRVs calculated using LRNI and EAR given as mg NE/1000 kcals (4.4 and 5.5, respectively). Calculated based on energy EAR for 15-18-year-old females (2110 kcals) and 19-50-year-old females (1940 kcals)

${ }^{\mathrm{f}}$ Vitamin B6 DRVs calculated using LRNI and EAR in $\mu \mathrm{g} / \mathrm{g}$ protein (11 and 13, respectively). Calculated based upon recommendations for $45 \mathrm{~g} /$ day of protein and converted into $\mathrm{mg}$

${ }^{\mathrm{g}}$ Energy EARs taken from COMA [33] for 15-18-year-old females (2110 kcals) and 19-50-year-old females (1940 kcals)

${ }^{\mathrm{h}}$ Ratios are for intake to EAR 


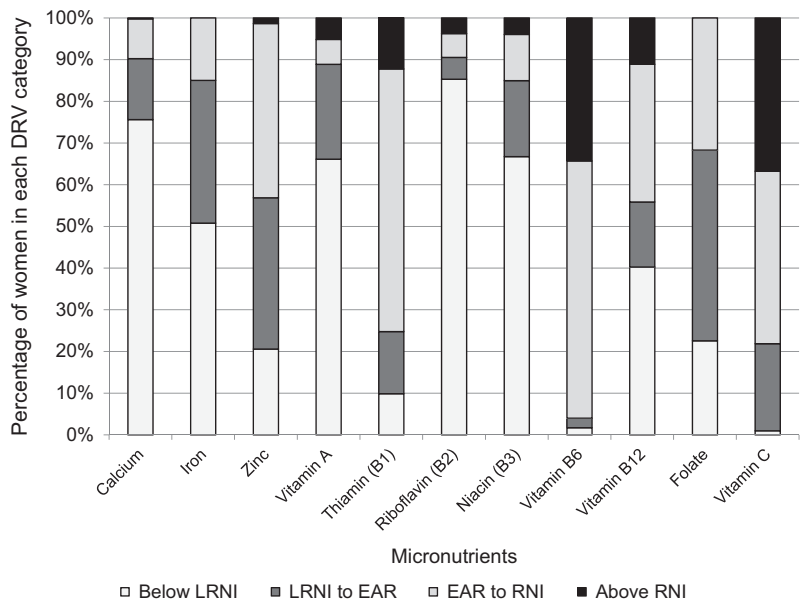

Fig. 1 Percentage of women achieving micronutrient dietary reference value intakes. Vitamin E is not included as there is no LRNI. Selenium and magnesium are not included, as the LRNI, EAR and RNI do not occur in order, so they do not conform to the categories in the legend

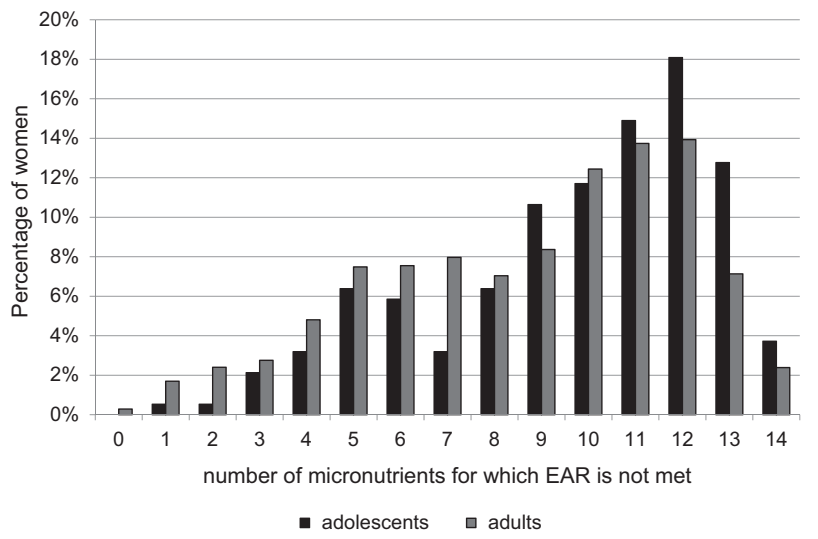

Fig. 2 Percentage of women with intakes of multiple micronutrients below the estimated average requirement (EAR)

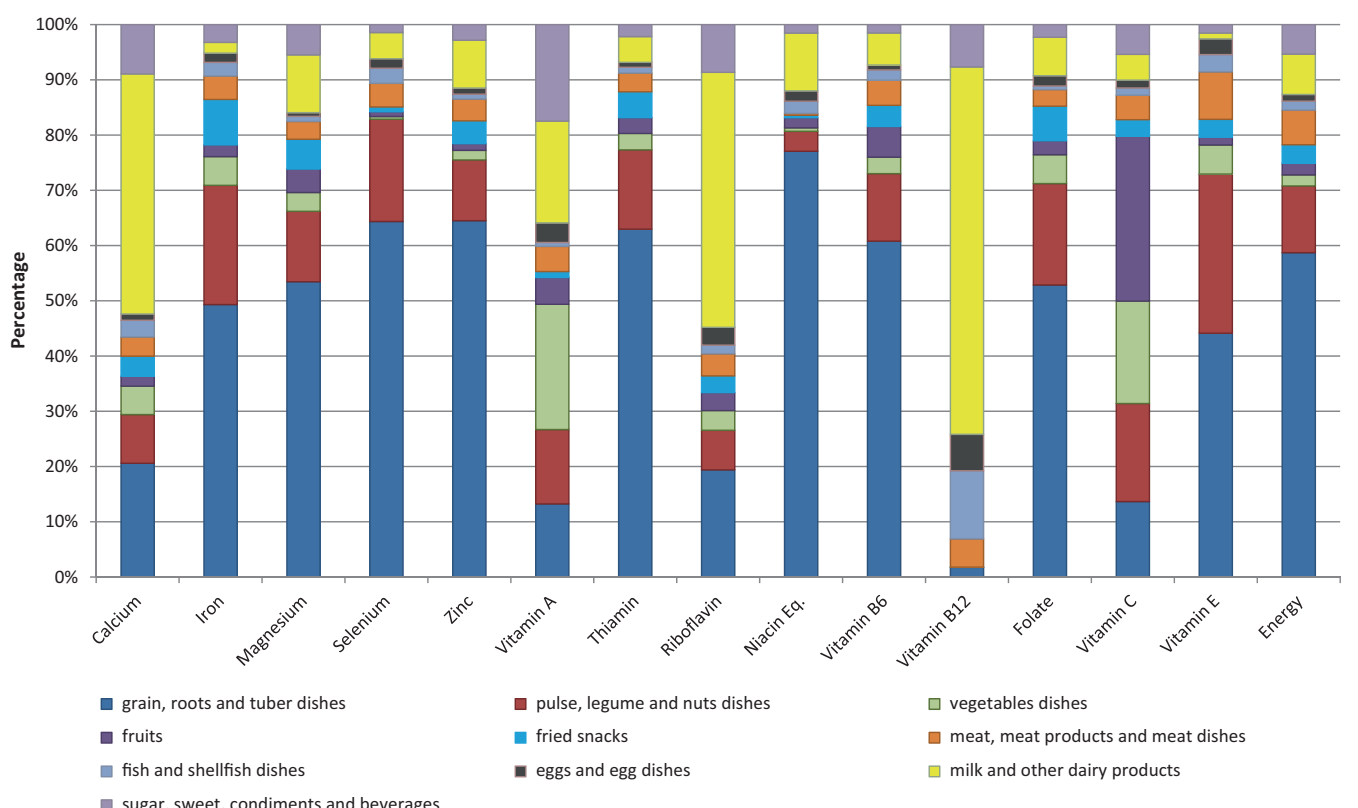

Fig. 3 Percentage of micronutrient and energy intakes from 10 food groups

\section{Adolescents}

Adolescent pregnancies carry higher risks of low birth weight and preterm birth, and children of adolescent mothers are at increased risk of stunting and low educational attainment [51]. DRVs for adults and adolescents differ based upon their requirements, with adolescents often requiring more due to ongoing growth. We found that adolescents had significantly lower intakes of magnesium, zinc, thiamine, niacin, vitamin B6 and vitamin $\mathrm{E}$ than adult women, and therefore may be at increased risk of deficiencies if they become pregnant.

\section{Dietary quality}

Consistent with other Indian studies, the women had low intakes of micronutrient-rich foods, such as animal source foods, fruit and vegetables [10, 26, 52]. Evidence suggests that poor-quality diets contribute to insufficiencies of multiple micronutrients [32,53], and adverse maternal and child outcomes [54]. Intakes of carbohydrate-rich foods were 
high in the sample, which can be common in Indian diets [20], especially in low-income households $[16,55]$. This may satisfy hunger and provide sufficient energy, but fails to provide the required quantities of micronutrients (e.g. vitamin B12 [56]) or bioavailable forms (e.g. iron [57]). Meat was consumed infrequently and in small quantities, and therefore contributed minimally to micronutrient intakes in this study. Pulses were important sources of energy, protein, iron, selenium, folate and vitamin C. Recent sharp price rises for pulses have made them unaffordable to poorer consumers and caused further reductions in protein consumption [58].

\section{Areas for further research}

Evidence is lacking on the determinants of poor nutrient intakes in urban slum populations. A study of the determinants would help to inform policy and interventions. There is a lack of evidence on how dietary intakes affect biochemical status, and whether dietary interventions can address deficiencies. International recommendations for improving micronutrient status focus mainly on pregnant and lactating women and young children, due to a strong evidence base of effectiveness $[5,9]$. There is growing evidence of the importance of good nutrition in the preconceptional period, but effective, sustainable and scalable interventions are lacking $[9,59,60]$.

\section{Conclusions}

Women of reproductive age living in Mumbai slums are consuming diets lacking in a number of important micronutrients, increasing their risk of deficiency, and, in turn, illhealth, adverse birth outcomes and suboptimal child development. There is a need to explore the factors causing poor intakes, in order to direct policy and programme interventions that improve the quality and nutritional sufficiency of diets of low-income women of reproductive age.

Acknowledgements This work was supported by the Wellcome Trust, United Kingdom; the Medical Research Council, United Kingdom; genomic and lifestyle predictors of foetal outcome relevant to diabetes and obesity and their relevance to prevention strategies in South Asian peoples (GIFTS); and the Industrial Credit and Investment Corporation of India Bank Ltd Social Initiatives Group, Mumbai, India. Data can be accessed by contacting the corresponding author.

\section{Compliance with ethical standards}

Conflict of interest The authors declare that they have no conflict of interest.

Publisher's note: Springer Nature remains neutral with regard to jurisdictional claims in published maps and institutional affiliations.
Open Access This article is licensed under a Creative Commons Attribution 4.0 International License, which permits use, sharing, adaptation, distribution and reproduction in any medium or format, as long as you give appropriate credit to the original author(s) and the source, provide a link to the Creative Commons license, and indicate if changes were made. The images or other third party material in this article are included in the article's Creative Commons license, unless indicated otherwise in a credit line to the material. If material is not included in the article's Creative Commons license and your intended use is not permitted by statutory regulation or exceeds the permitted use, you will need to obtain permission directly from the copyright holder. To view a copy of this license, visit http://creativecommons. org/licenses/by/4.0/.

\section{References}

1. Darnton-Hill I, Mkparu UC. Micronutrients in pregnancy in lowand middle-income countries. Nutrients. 2015;7:1744-68.

2. Jiang TN, Christian P, Khatry SK, Wu L, West KP. Micronutrient deficiencies in early pregnancy are common, concurrent, and vary by season among rural nepali pregnant women. $J$ Nutr. 2005; 135:1106-12.

3. Salam RA, Das JK, Bhutta ZA. Multiple micronutrient supplementation during pregnancy and lactation in low-to-middleincome developing country settings: impact on pregnancy outcomes. Ann Nutr Metab. 2014;65:4-12.

4. Bhutta ZA, Salam RA, Das JK. Meeting the challenges of micronutrient malnutrition in the developing world. Br Med Bull. 2013;106:7-17.

5. World Health Organization. Essential nutrition actions: improving maternal, newborn, infant and young child health and nutrition. Geneva: World Health Organization; 2013.

6. Black R. Micronutrient deficiency - an underlying cause of morbidity and mortality. Bull World Health Organ. 2003;81:79-79.

7. Bhaskaram P. Micronutrient malnutrition, infection, and immunity: an overview. Nutr Rev. 2002;60:S40-S45.

8. Kassu A, Yabutani T, Mulu A, Tessema B, Ota F. Serum zinc, copper, selenium, calcium, and magnesium levels in pregnant and non-pregnant women in Gondar, northwest Ethiopia. Biol Trace Elem Res. 2008;122:97-106.

9. Bhutta ZA, Das JK, Rizvi A, Gaffey MF, Walker N, Horton S, et al. Evidence-based interventions for improvement of maternal and child nutrition: what can be done and at what cost? Lancet. 2013;382:452-77.

10. Kapil U, Pathak P, Tandon M, Singh C, Pradhan R, Dwivedi SN. Micronutrient deficiency disorders amongst pregnant women in three urban slum communities of Delhi. Indian Pediatr. 1999;36:983-9.

11. Pathak P, Kapil U, Kapoor SK, Saxena R, Kumar A, Gupta N, et al. Prevalence of multiple micronutrient deficiencies amongst pregnant women in a rural area of Haryana. Indian $\mathrm{J}$ Pediatr. 2004;71:1007-14.

12. International Institute for Population Sciences (IIPS) and Macro International. National Family Health Survey (NFHS-3), India, 2005-06: Maharashtra. Mumbai: International Institute for Population Sciences; 2008.

13. Goonewardene M, Shehata M, Hamad A. Anaemia in pregnancy. Best Pract Res Clin Obstet Gynaecol. 2012;26:3-24.

14. Barker D. Mothers, babies and health in later life. Edinburgh, UK: Churchill Livingstone; 1998.

15. Ploysangam A, Falciglia GA, Brehm BJ. Effect of marginal zinc deficiency on human growth and development. J Trop Pediatr. 1997;43:192-8. 
16. Nguyen PH, Nguyen H, Gonzalez-Casanova I, Copeland E, Strizich G, Lowe A, et al. Micronutrient intakes among women of reproductive age in Vietnam. Plos One. 2014;9:9.

17. Allen LH. Multiple micronutrients in pregnancy and lactation: an overview. Am J Clin Nutr. 2005;81:1206S-1212S.

18. Darnton-Hill I, Webb P, Harvey PWJ, Hunt JM, Dalmiya N, Chopra M, et al. Micronutrient deficiencies and gender: social and economic costs. Am J Clin Nutr. 2005;81:1198S-1205S.

19. Briones Alonso E. The impact of culture, religion and traditional knowledge on food and nutrition security in developing countries. Food Secure, 2015.

20. Isharwal S, Misra A, Wasir JS, Nigam P. Diet \& insulin resistance: a review \& Asian Indian perspective. Indian J Med Res. 2009;129:485-99.

21. Misra A, Khurana L, Isharwal S, Bhardwaj S. South Asian diets and insulin resistance. Br J Nutr. 2009;101:465-73.

22. National Institute of Nutrition. Report of Urban survey-slums (1993-94). Hyderabad: Indian Council of Medical Research; 1994.

23. Radhika G, Sudha V, Sathya RM, Ganesan A, Mohan V. Association of fruit and vegetable intake with cardiovascular risk factors in urban south Indians. Br J Nutr. 2008;99:398-405.

24. Murty KV, Reddy KJ. Dietary patterns and selected anthropometric indices in reproductive age women of a slum in urban: Kurnool. Indian J public health. 1994;38:99-102.

25. Chopra H, Chheda P, Kehoe S, Taskar V, Brown N, Shivashankaran D, et al. Dietary habits of female urban slum-dwellers in Mumbai. Indian J Matern Child Health. 2012;14:1-13.

26. Rao S, Yajnik CS, Kanade A, Fall CHD, Margetts BM, Jackson $\mathrm{AA}$, et al. Intake of micronutrient-rich foods in rural Indian mothers is associated with the size of their babies at birth: Pune maternal nutrition study. J Nutr. 2001;131:1217-24.

27. Andersen LT, Thilsted SH, Nielsen BB, Rangasamy S. Food and nutrient intakes among pregnant women in rural Tamil Nadu, South India. Public Health Nutr. 2003;6:131-7.

28. Torheim LE, Ferguson EL, Penrose K, Arimond M. Women in resource-poor settings are at risk of inadequate intakes of multiple micronutrients. J Nutr. 2010;140:2051S-2058S.

29. Potdar RD, Sahariah SA, Gandhi M, Kehoe SH, Brown N, Sane $\mathrm{H}$, et al. Improving women's diet quality preconceptionally and during gestation: effects on birth weight and prevalence of low birth weight-a randomized controlled efficacy trial in India (Mumbai Maternal Nutrition Project). Am J Clin Nutr. 2014;100:1257-68.

30. International Institute for Population sciences (IIPS) and Operations Research Centre (ORC) Macro. National Family Health Survey (NFHS-2), India, 1998-99. Maharashtra: International Institute for Population Sciences Mumbai; 2000.

31. The Food Standards Agency. McCance \& Widdowson's The composition of foods integrated dataset. Version 6, Sixth summary edition. Cambridge: The Stationary Office; 2002.

32. World Health Organization and Food and Agriculture Organization of the United Nations. Vitamin and mineral requirements in human nutrition. 2nd edn. Rome: Report of a Joint FAO/WHO Expert Consultation. Food and Agriculture Organization; 2004.

33. Committee on Medical Aspects of Food Policy. Dietary reference values for food energy and nutrients for the United Kingdom. Report of the Panel on Dietary Reference Values of the Committee on Medical Aspects of Food Policy. Rep health Soc Subj. 1991;41:1-210.

34. Institute of Medicine Panel on Dietary Antioxidants and Related Compounds. Vitamin E. In: Dietary reference intakes for vitamin C, vitamin E, selenium, and carotenoids. National Academies Press (US): Washington (DC); 2000, pp 186-262.

35. Institute of Medicine Panel on Dietary Antioxidants and Related Compounds. Selenium. In: Dietary reference intakes for vitamin
C, vitamin E, selenium, and carotenoids. National Academies Press (US): Washington (DC); 2000, pp 284-319.

36. Nair KM, Iyengar V. Iron content, bioavailability \& factors affecting iron status of Indians. Indian $\mathrm{J}$ Med Res. 2009;130:634-45.

37. Kalasuramath S, Kurpad AV, Thankachan P. Effect of iron status on iron absorption in different habitual meals in young south Indian women. Indian J Med Res. 2013;137:324-30.

38. National Institute of Nutrition. Dietary guidelines for Indians-a manual. Hyderabad, India: Indian Council of Medical Research; 2011.

39. Becquey E, Martin-Prevel Y. Micronutrient adequacy of women's diet in urban Burkina Faso is low. J Nutr. 2010;140:2079S-2085S.

40. Seshadri S. Prevalence of micronutrient deficiency particularly of iron, zinc and folic acid in pregnant women in South East Asia. Br J Nutr. 2001;85:S87-S92.

41. Henjum S, Manger M, Skeie E, Ulak M, Thorne-Lyman AL, Chandyo R, et al. Iron deficiency is uncommon among lactating women in urban Nepal, despite a high risk of inadequate dietary iron intake. Br J Nutr. 2014;112:132-41.

42. Songchitsomboon S, Komindr S, Phuapradit W, Sirivarasai J. Zinc and copper status in urban Thai pregnant women and their pregnancy outcome. Biomed Environ Sci. 1998;11:156-64.

43. Al Khatib L, Obeid O, Sibai AM, Batal M, Adra N, Hwalla N. Folate deficiency is associated with nutritional anaemia in Lebanese women of childbearing age. Public Health Nutr. 2006;9:921-7.

44. Thoradeniya T, Wickremasinghe R, Ramanayake R, Atukorala S. Low folic acid status and its association with anaemia in urban adolescent girls and women of childbearing age in Sri Lanka. Br J Nutr. 2006;95:511-6.

45. Alarcon K, Kolsteren PW, Prada AM, Chian AM, Velarde RE, Pecho IL, et al. Effects of separate delivery of zinc or zinc and vitamin A on hemoglobin response, growth, and diarrhea in young Peruvian children receiving iron therapy for anemia. Am J Clin Nutr. 2004;80:1276-82.

46. Solomons NW. Competitive interaction of iron and zinc in the diet - consequences for human nutrition. J Nutr. 1986;116:927-35.

47. Whittaker P. Iron and zinc interactions in humans. Am J Clin Nutr. 1998;68:442S-446S.

48. Bailey RL, West KP, Black RE. The epidemiology of global micronutrient deficiencies. Ann Nutr Metab. 2015;66:22-33.

49. Bloem MW. Interdependence of vitamin A and iron-an important association for programs of anaemia control. Proc Nutr Soc. 1995;54:501-8.

50. Thankachan P, Walczyk T, Muthayya S, Kurpad AV, Hurrell RF. Iron absorption in young Indian women: the interaction of iron status with the influence of tea and ascorbic acid. Am J Clin Nutr. 2008;87:881-6.

51. Fall CHD, Sachdev HS, Osmond C, Restrepo-Mendez MC, Victora $\mathrm{C}$, Martorell R, et al. Association between maternal age at childbirth and child and adult outcomes in the off spring: a prospective study in five low-income and middle-income countries (COHORTS collaboration). Lancet Glob Health. 2015;3: E366-E377.

52. Arnold FPS, Arokiasamy P, Kothari M. Nutrition in India. National Family Health Survey (NFHS-3), India, 2005-06. Mumbai: International Institute for Population Sciences; Calverton, Maryland, USA: ICF Macro; 2009.

53. Arsenault JE, Yakes EA, Islam MM, Hossain MB, Ahmed T, Hotz C, et al. Very low adequacy of micronutrient intakes by young children and women in rural Bangladesh is primarily explained by low food intake and limited diversity. J Nutr. 2013;143:197-203.

54. Victora CG, Adair L, Fall C, Hallal PC, Martorell R, Richter L, et al. Maternal and child undernutrition 2-Maternal and child 
undernutrition: consequences for adult health and human capital. Lancet. 2008;371:340-57.

55. Nguyen PH, Strizich G, Lowe A, Nguyen H, Pham H, Truong TV, et al. Food consumption patterns and associated factors among Vietnamese women of reproductive age. Nutr J. 2013;12:11.

56. Allen LH. To what extent can food-based approaches improve micronutrient status? Asia Pac J Clin Nutr. 2008;17(Suppl 1):103-5.

57. Bouis HE, Eozenou P, Rahman A. Food prices, household income, and resource allocation: socioeconomic perspectives on their effects on dietary quality and nutritional status. Food Nutr Bull. 2011;32:S14-23.
58. Kishore A, Hoddinott JF, Joshi PK. India's right to food act: a novel approach to food security. 2013 Global food policy report. Washington, DC: International Food Policy Research Institute (IFPRI); 2014. p. 29-42.

59. Dominguez-Salas P, Moore SE, Cole D, da Costa KA, Cox SE, Dyer RA, et al. DNA methylation potential: dietary intake and blood concentrations of one-carbon metabolites and cofactors in rural African women. Am J Clin Nutr. 2013;97:1217-27.

60. Dominguez-Salas P, Moore SE, Baker MS, Bergen AW, Cox SE, Dyer RA, et al. Maternal nutrition at conception modulates DNA methylation of human metastable epialleles. Nat Commun. 2014;5:7. 